\title{
Community structure of corticolous microalgae within a single forest stand: evaluating the effects of bark surface $\mathrm{pH}$ and tree species
}

\author{
Anna ŠTiFTERovÁ \& Jiří NeUSTUPA*
}

Department of Botany, Faculty of Science, Charles University Prague, Benátská 2, Prague, CZ-128 01, Czech

Republic; *Corresponding author e-mail:neustupa@natur.cuni.cz

\begin{abstract}
Community structure of corticolous macro-epiphytes, such as lichens and mosses, usually strongly correlates with bark characteristics related to the taxonomic identity of the host tree. However, the reasons for the occurrence of similar patterns of microalgal corticolous biofilms are unclear and have rarely been investigated. In this study, we surveyed aerial phototrophic biofilms growing on the bark of Acer, Alnus, Fagus, Fraxinus and Picea trees in a single stand of a temperate forest. A flathead electrode was used to measure and evaluate the effect of bark surface $\mathrm{pH}$ on microalgal species richness and composition. In total, 47 distinct morphotypes were found, chiefly consisting of various coccoid green algae belonging to Trebouxiophyceae and Chlorophyceae. In addition, members of the Bacillariophyceae, Eustigmatophyceae, Streptophyta, Trentepohliales, Xanthophyceae and Cyanobacteria were also found. Bark $\mathrm{pH}$ and species richness of the samples were positively correlated; in the most acidic samples (from Picea and Alnus trees), only green algae occured. Aerial diatoms, Cyanobacteria, Xanthophyceae and Trentepohlia sp. were only found in the more basic samples. The species composition was significantly structured by the separated effects of host tree species, the bark $\mathrm{pH}$ and the sampling season. The observed non-random differences in community structure of the biofilms among host tree species indicated possible effects of deterministic processes, such as species sorting of microalgae along the environmental gradients.
\end{abstract}

Key words: Algae and Cyanobacteria, Bark pH, Biodiversity, Corticolous biofilms, Epiphyte ecology, Trebouxiophyceae

\section{INTRODUCTION}

Corticolous microalgae form diversified communities on the tree bark surface (GÄRTNER 1994; FREYSTEIN \& ReISSER 2010; Kulichová et al. 2014) and constitute an important part of phototrophic epiphytic biodiversity in these common microhabitats (ElLis 2012). However, the ecology of the corticolous algae is poorly understood, especially in comparison with the corticolous lichens and bryophytes. Most of the microalgal taxa occurring in tree bark biofilms are small (c. 5-15 $\mu \mathrm{m}$ ), unicellular, coccoid organisms (ETTL \& GÄRTNER 1995). This simple morphology has often been explained as a functional adaptation of the aerial algae, which have to survive in places where they are often exposed to extreme environmental conditions, such as frequent desiccation, high irradiance and temperature fluctuations (LoPEZ-BAUTISTA et al. 2007; BÜDEL 2011). In addition to morphological adaptations, the members of the phototrophic aerial biofilms also possess various ecophysiological strategies, such as high intracellular osmotic values to avoid the water loss, high UV tolerance, or photoprotection for survival in these harsh microhabitats (KarsTen \& Holzinger 2014; KITZING et al. 2014).

The dominants of the microalgal autotrophic corticolous communities are chiefly green coccoid algae belonging to Trebouxiophyceae and Chlorophyceae, along with the filamentous Cyanobacteria and Trentepohliales (ETTL \& GärtNer 1995; FreysteIn et al. 2008; Neustupa \& Štifterová 2013). Traditional taxonomy of these organisms, based on their cellular morphology, generally underestimates their true phylogenetic diversity (RINDI et al. 2009; FrIEDL \& RYBALKA 2012). Consequently, a number of new coccoid taxa were recently described using molecular methods (NĚMCovÁ et al. 2011; MA et al. 2013; Neustupa et al. 2013). However, despite the low morphological diversity of corticolous microalgae, their ecology and community structure can still be successfully studied using a combination of cultivation techniques and detailed light microscopy. Individual morphological taxa, corresponding to tentative species or higher-level lineages, can be identified into operational taxonomic units (OTUs) and used in subsequent ecological analyses. Still, such studies are relatively labourious, as they 
typically involve microscopic inspection of numerous Petri dishes, typically with hundreds of algal microcolonies. Alternatively, community structure of corticolous algae may also be studied by direct microscopy of biofilms (HEDENÅs et al. 2007; LEMES-DA-SiLva et al. 2012; Neustupa \& ŠTIFTERovÁ 2013). This method allows relatively large numbers of samples to be surveyed, but it lacks taxonomic resolution among many species and genera, especially the coccoid green algae. This method is thus suitable for studies where identification into the higher taxa is sufficient. The molecular diversity of biofilms can be ascertained using a variety of methods, including cultivation-independent analyses of the community metagenome (CUTLER et al. 2013; DAvies et al. 2013). However, these studies are still essentially constrained by the relatively low number of samples that can be realistically processed. Consequently, ecological interpretability of such results remains limited. Therefore, cultivation-based studies still provide an efficient way of investigating corticolous algal biofilms, as they provide moderate taxonomic resolution, but can be based on a relatively high number of samples processed for community structure analysis.

Studies dealing with canopy lichen and moss flora have repeatedly shown that communities of corticolous mosses and lichens are structured over various scales. Tree age, the height of the sampling spot and factors related to canopy openness, such as irradiance, humidity, temperature and wind velocity, were identified as important mesoscale factors, differentiating cryptogamic corticolous communities among trees of a single forest stand (BARKMAN 1958; MCCUNE et al. 2000; CARUso \& Thor 2007; RAmbo 2010). Bark structure and (especially) the bark surface $\mathrm{pH}$ levels have also repeatedly been recognised as crucial factors shaping corticolous communities of mosses and lichens (BARKman 1958; GonZalez-Mancebo et al. 2003). However, some recent studies have also suggested that the effect of $\mathrm{pH}$ may be limited (LARSEN et al. 2007), and differences among corticolous communities of lichens and mosses on different host tree species can be also caused by factors not correlated with bark $\mathrm{pH}$ values (SPIER et al. 2010). The taxonomic identity of a host tree species has frequently been neglected or underestimated, because bark $\mathrm{pH}$ largely varies within tree species (BARKMAN 1958; STUDLAR 1982; GonZALEZ-MANCEBo et al. 2003; Lewis \& ElLis 2010).

Much less data are available on the ecology of corticolous algae and cyanobacteria. In general, it can be stated that these communities, although composed of easily dispersed microorganisms living on a seemingly uniform substrate, such as tree bark, are undoubtedly structured. At the mesoscale level (within a single forest stand), HeDENÅs et al. (2007) demonstrated the influence of light conditions and tree age on the occurrence of individual dominant microalgae on the bark of poplar trees (Populus tremula). LÜtTGE \& Bü-
DEL (2010) showed that individual major components of microalgal corticolous biofilms, such as coccoid green algae and Trentepohliales, considerably differ in their desiccation tolerance, which may determine their occurence in natural habitats. In addition, FREYSTEIN et al. (2008) demonstrated that individual morphological taxa occuring on tree bark differ in their air pollution tolerance in urban habitats. These findings led the authors to consider the role of these microorganisms as possible bioindicators of air quality (FREYSTEIN et al. 2008). Neustupa \& ŠKaloud (2008) illustrated the significant effects of the varying irradiance of trunks on microalgal species diversity and composition in tropical forest habitats. The authors also proved that the sample $\beta$-diversity (species turnover among samples) is higher on decaying logs than on living trees. On a regional scale, several studies conducted in Scandinavia revealed a significant increase in the abundance of microalgal corticolous biofilms, which correlates with increased atmospheric nitrogen deposition (HÄNNINEN et al. 1993; Poikolainen et al. 1998). In a recent multi-scale study; Neustupa \& ŠTifTERová (2013) studied the distribution patterns of microalgal groups thriving in corticolous microhabitats in two European regions. Bark $\mathrm{pH}$, which correlates with the host tree species, was found to be particularly important for the distribution of the Trentepohliales and Cyanobacteria. Conversely, the distribution of trebouxiophycean coccoid green algae is primarily related to microscale factors, such as the height or orientation of samples on trunks. Marmor \& Degtjarenko (2014) observed that presence of conspicuous covers of Trentepohlia umbrina on usually acidic bark of Scots pine (Pinus sylvestris) in Estonia was correlated with alkaline dust pollution and thus with the levels of $\mathrm{pH}$.

In this study, we asked whether bark $\mathrm{pH}$, as well as other factors that were correlated with differences among individual host tree species, would prove significant for structuring the microalgal corticolous community at the mesoscale level, i.e., among trees in a single temperate mixed forest stand. This study was based on the cultivation of bark samples and subsequent microscopic identification of individual microcolonies growing on agar plates. Therefore, identification was not limited to major taxa, such as the Trebouxiophyceae or Cyanobacteria. Conversely, a number of OTUs belonging to coccoid green algae could be discerned and their distribution compared among individual trees. We presumed that these easily dispersible, smallcelled taxa probably do not have any dispersal limitations among different tree trunks of a single 3 ha forest stand. Therefore, if the bark of different forest trees is a homogeneous substrate for these taxa, their species composition should be quite similar. Conversely, any significant or non-random difference in species composition of biofilms among tree species would indicate the effects of bark $\mathrm{pH}$ or other abiotic factors acting at the host tree species level. 


\section{Material And Methods}

Sampling. Samples were taken in an area of approximately 3 ha in a temperate mixed forest in České středohoří Mts., northwestern Czech Republic (50³2'53"N, 135' 12 "E, altitude 570-620 $\mathrm{m}$ a.s.1.). The samples were collected four times: in August 2010, March 2011, May 2011 and June 2011. In total, 32 individual trees of the following five genera were sampled: alder, Alnus glutinosa (Betulaceae); ash, Fraxinus excelsior (Oleaceae); beech, Fagus sylvatica (Fagaceae); maple, Acer platanoides, A. pseudoplatanus (Sapindaceae); and spruce, Picea abies (Pinaceae). All of the examined trees had straight growth, vital appearance without visible wounds and a trunk diameter of at least $20 \mathrm{~cm}$ at a height of 160 $\mathrm{cm}$. Pieces of bark (approximately $5 \mathrm{~cm}^{2}$ ) were peeled off from around the trunk at a height of $160 \mathrm{~cm}$ and immediately placed into sterile bags. This sampling design was chosen to limit microscale effects (such as height or orientation aspect on the trunk). The bark $\mathrm{pH}$ was measured in the laboratory using a WTW pH-330 set with a flathead electrode (SenTix Sur). The direct measuring of bark surface $\mathrm{pH}$ with flathead electrode has recently become a standard practice in various forestry, as well as ecological studies (e.g., CÁCEREs et al. 2007; MARMOR et al. 2010). As the procedure does not involve breakage of the bark and is more likely to record the bark surface $\mathrm{pH}$ that is actually experienced by the epiphytes, it is believed that it provides more relevant values than previously used methodologies (such as $\mathrm{pH}$ measuring of the solvent of soaked bark fragments in deionised water; ScHMIDT et al. 2001). In total, $0.5 \mathrm{ml}$ of $0.1 \mathrm{M} \mathrm{KCl}$ in water was dropped onto individual pieces of clean bark surfaces $1 \mathrm{~min}$ prior to measurement (MARMOR \& RANDLANE 2007; RAMBO 2010). The final $\mathrm{pH}$ values, used in the statistical analyses, are the means of two separate measurements from each surveyed tree.

Cultivation and identification. The cultivation-based studies always suffer from the selectiveness of the growth media, which could facilitate or restrain growth of certain species and thus affect the observed diversity. However, in this study, we strived to maximize the number of processed samples and to acquire comparable data for ecological interpretations. Therefore, we used the standard Bold Basal Medium (ANDERSEN et al. 2005), which has been originally designed for culturing terrestrial green microalgae and it has also proved to be convenient and supporting growth of a great variety of microalgae from the aerial microhabitats (e.g., EtTl \& GÄrtner 1995; Freystein et al. 2008; Neustupa \& ŠKALOUD 2008).

In the laboratory, the algal biofilm was scraped off the samples with a sterile stylus and placed into $1.5 \mathrm{ml} \mathrm{Ep-}$ pendorf tubes containing $0.5 \mathrm{ml}$ liquid Bold Basal Medium (BBM). Then, sterile glass beads $(0.5 \mathrm{~mm}$ in diameter) were added to the tube, which was shaken for 15 seconds at 1200 rpm in a vortex mixer. The resulting suspension was inoculated onto two Petri plates containing agar-solified BBM. After 3-5 weeks of cultivation (12:12 h L:D regime at $20^{\circ} \mathrm{C}$, irradiance c. $60 \mu \mathrm{mol} . \mathrm{m}^{-2} \cdot \mathrm{s}^{-1}$ ), the plates were examined. The algal microcolonies were morphologically identified under an Olympus BX 31 microscope at a magnification of $\times 400$ 1000 , at the lowest taxonomic level that could be unambiguously distinguished using relevant references (e.g., ЕтTL \& Gärtner 1995; KomÁreK \& ANAGNostidis 2005; MikhaILYUK et al. 2008; RINDI et al. 2011). In some cases, tentative identification at the species level was possible, but many taxa were identified as genera, or tentatively named morphotypes, which were used as individual operational taxonomic units (OTUs). The assessment of the semi-quantities of individual morphotypes in samples was based on assumption that each inspected microcolony originated from a single cell, colony, or a filament present in the original sample. In a given plate, after inspecting approximately 100 distinct colonies, the percentage proportions of each recognised morphotype were recorded. These values were then converted to a semi-quantitative scale (0: absence; $1: 1-10 \% ; 2: 11-40 \% ; 3: 41-100 \%)$. In parallel, a second dataset, including community structure data converted into a binary scale (presence/absence), was also evaluated.

Data analysis. The differences in bark $\mathrm{pH}$ values and microalgal species richness among individual host tree species were tested using the Kruskal-Wallis test in PAST, ver. $2.17 \mathrm{c}$ (HAMMER et al. 2001). The separation of effects of individual abiotic variables on biofilm community composition were investigated using two parallel approaches. Multivariate redundancy analysis (RDA) was carried out in the vegan package (OKSANEN et al. 2011) in R, ver. 2.15.3 (R DeVELopMEnt Core TeAm 2013). The percentages of the variance explained by individual factors, including the bark $\mathrm{pH}$ value, time and host tree species, could thus be determined as the adjusted $\mathrm{R}^{2}$ values acquired by the function varpart of the vegan package. In addition, permutational analysis of variance (Per-MANOVA), implemented by the function adonis of the vegan package, was also used. The community structure was illustrated by non-metric MDS ordination analysis, implemented in PAST, ver. 2.17c. Sample-based (Mao Tau) rarefaction curves (CoLweLl et al. 2004) were used to illustrate the relationship between the number of investigated samples and the species diversity. These rarefaction curves, as well as their $5-95 \%$ confidence intervals, were calculated in PAST, ver. $2.17 \mathrm{c}$

\section{Results}

\section{Species identification}

The tree bark biofilms examined in this study harboured diverse microalgal communities. In total, 47 distinct morphotypes of aerial corticolous microalgae and Cyanobacteria were recognised (Electronic Appendix $1)$. The vast majority (79\%) of morphotypes belonged to the green algal classes Trebouxiophyceae and Chlorophyceae (Fig. 1). In addition, members of the Bacillariophyceae, Eustigmatophyceae, Streptophyta, Trentepohliales, Xanthophyceae and Cyanobacteria were also identified. Samples taken from trees with the most acidic bark $\mathrm{pH}$ values, i.e., alder and spruce, were composed solely of the green algal morphotypes. Conversely, Cyanobacteria were only found on the bark of beech and maple trees, and diatoms occured only in two samples taken from maple trees (Fig. 2).

Populations of the aerial genus Trentepohlia (Figs 3-4) were found in various ash, beech and maple samples. The non-lichenised cells identified as Trebouxia or Asterochloris (Fig. 5) were found in 
Table 1. Results of permutational multivariate analyses of variance (Per-MANOVA) evaluating the controlled effects of individual factors on community structure. The Manhattan distance index (semi-quantities) and the Jaccard similarity index (presence/absence) were used for calculations.

\begin{tabular}{lllllll} 
Semi-quantities & \multicolumn{7}{l}{} & & & \\
Factor & Df & Sums of Squares & Mean Squares & $\mathrm{F}$ & $\mathrm{R}^{2}$ & $\mathrm{p}$-value \\
time & 1 & 349.0 & 349.03 & 5.31 & 0.10427 & $<0.0001$ \\
tree & 4 & 658.1 & 164.54 & 2.94 & 0.19661 & 0.0002 \\
$\mathrm{pH}$ & 1 & 366.9 & 366.9 & 5.56 & 0.10960 & $<0.0001$ \\
Presence/absence & & & & & & $\mathrm{p}$-value \\
Factor & $\mathrm{Df}$ & Sums of Squares & Mean Squares & $\mathrm{F}$ & $\mathrm{R}^{2}$ & \\
time & 1 & 0.7834 & 0.78339 & 3.57 & 0.08918 & $<0.0001$ \\
tree & 4 & 1.66 & 0.42164 & 1.99 & 0.19200 & $<0.0001$ \\
$\mathrm{pH}$ & 1 & 0.3942 & 0.39419 & 1.97 & 0.04488 & 0.0217 \\
\hline
\end{tabular}

various alder, beech, maple and spruce samples. The ubiquitous filamentous alga Klebsormidium sp. (Fig. 6) was found in alder, beech, ash and maple samples. The most frequent OTUs (found in more than $50 \%$ of the samples) were Stichococcus bacillaris (Fig. 7), Apatococcus lobatus (Fig. 8), Interfilum terricolum (Fig. 9) and Dictyochloropsis irregularis (Fig. 10). Likewise, Apatococcus lobatus, Coccomyxa sp. 2 (Fig. 11), Pseudococcomyxa sp. (Fig. 12), Chloroidium ellipsoideum (Fig. 13) and Stichococcus bacillaris were encountered on all host tree species. Conversely, 21 OTUs (45\%) were found on a single host tree species (12 on maple, four on beech, three on ash, one on alder, one on spruce. In total, 17 OTUs (36\%) were only encountered in a single sample, for example Pseudanabaena sp. (Fig. 14), Nostoc sp. (Fig. 15), the diatom taxa Hantzschia amphioxys (Fig. 16) and Luticola mutica (Fig. 17) and the distinctive xanthophycean alga Botrydiopsis constricta (Fig. 18).

\section{Diversity and community structure}

The $\mathrm{pH}$ values of the bark surface differed significantly among individual host tree species (Kruskal-Wallis test, $\mathrm{p}=0.0009$ ). Spruce (Picea abies) had the most acidic bark (mean $\mathrm{pH} 3.47$ ), which reflects the general pattern of bark acidity in gymnosperms (BARKMAN 1958). Conversely, the angiosperms had relatively high pH values. Maple (Acer platanoides, A. pseudoplatanus) and ash (Fraxinus excelsior) generally had the highest bark pH values (Fig. 19). Likewise, the differences in microalgal species richness among host tree species were highly significant (Kruskal-Wallis test, $p$ $=0.0004$ ). The number of OTUs found in a single sample ranged from two to 20 , with a mean value of nine. The bark $\mathrm{pH}$ and the species richness of the samples were positively correlated (Fig. 20). In total, 11 OTUs were recovered from the spruce samples, with an average of 3.7 OTUs found in a single spruce sample.
By contrast, samples taken from maple bark contained a total of 36 OTUs, with an average of 12.8 OTUs in a single sample.

The unsaturated relationship between the number of processed samples and the total species richness indicates that more OTUs would be uncovered with additional sampling efforts (Fig. 21). However, the rarefaction curves clearly differed among individual host tree species (Fig. 22), and this pattern could not be easily compared to the $\mathrm{pH}$ and species richness gradient. Interestingly, the rarefaction curve of the beech samples, typified by intermediate $\mathrm{pH}$ values, was very similar to the maple curve, which implies that the high total species richness of algal epiphytes may be similar for both of these tree taxa.

Permutational multivariate analyses of variance (Per-MANOVA) demonstrated that the separated effects of host tree species, bark surface $\mathrm{pH}$ and temporal factors significantly structured the observed algal species composition (Table 1). These effects were recognised for both the semi-quantitative and presence/absence species data matrices. In parallel, partition of the variance spanned by individual abiotic factors illustrated that temporal factors were important for the community structure of the corticolous microalgae (Figs 23-24). The effect of time was markedly more prominent for the semi-quantitative species data than for the presence/absence matrix. The $\mathrm{pH}$ values of the bark surface were also important, but the independent effects of the host tree species (i.e., controlled for the effects of both $\mathrm{pH}$ and time) on the biofilm composition were consistently more conspicuous. The substantial effect of the host tree species on the epiphytic microalgal community structure was also illustrated in non-metric MDS ordination diagrams (Figs 25-26). Although the host tree clusters, consisting of samples taken from individual tree species, were typically not entirely separated, they overlapped only partially. The 


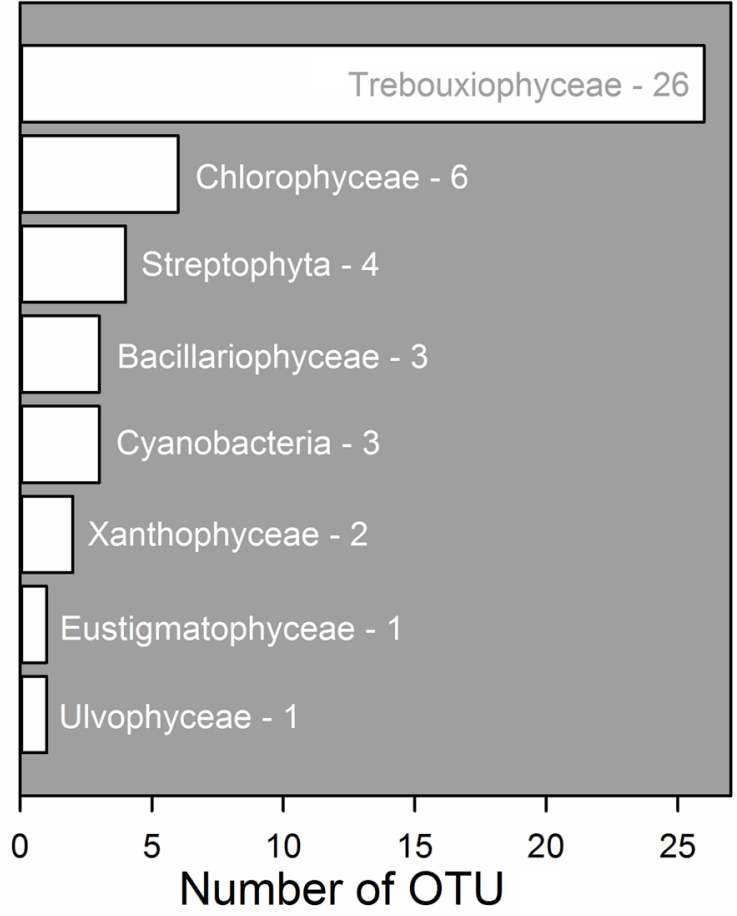

Fig. 1. Number of OTUs from individual major microalgal groups found in the samples.

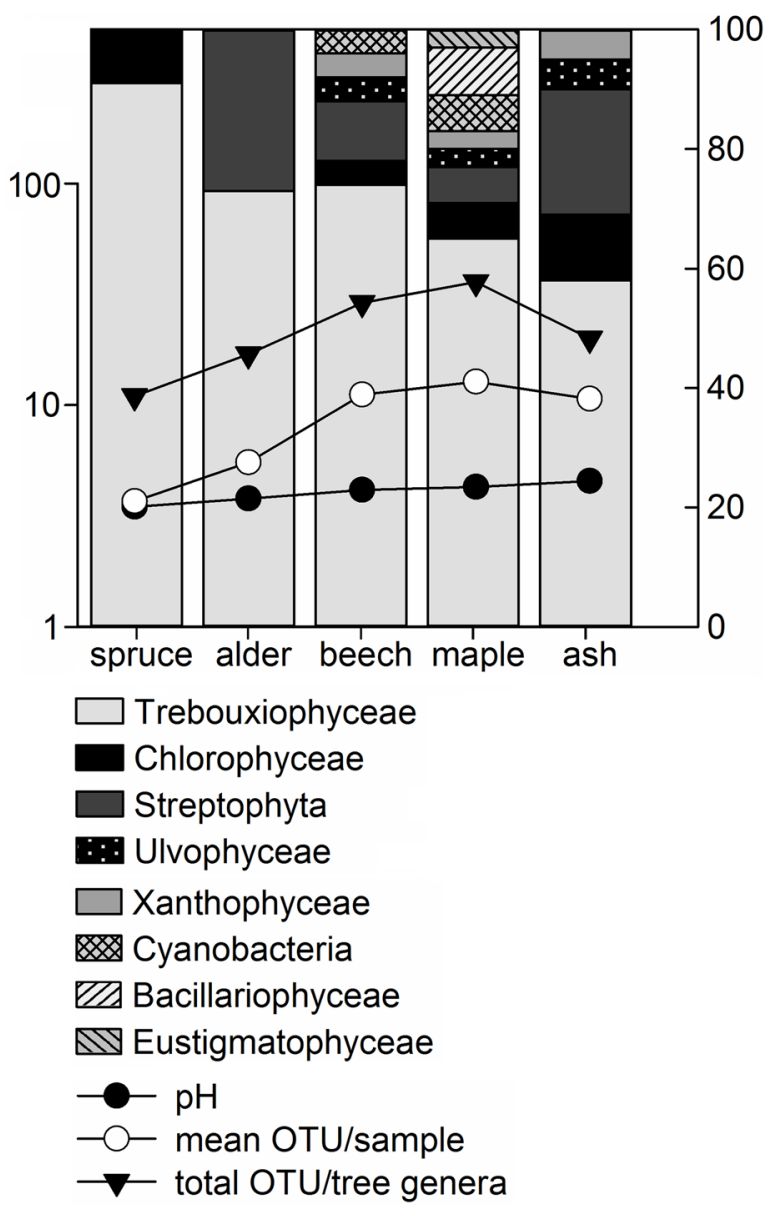

Fig. 2. Proportional representation of individual microalgal groups and bark $\mathrm{pH}$ levels in samples taken from different tree species. The logarithmic scale (left vertical axis) relates to the line charts. proportion of variation explained by the host tree species differed between the two species data matrices. In the semi-quantitative data, this factor determined $6.57 \%$ of variability, but it determined $9.32 \%$ of variability in the presence/absence matrix (Figs 23-24).

\section{Discussion}

The tree bark of the investigated trees harboured diverse microalgal communities. On average, there were nine OTUs found on a single tree. Such local species richness corresponds more closely to values reported for tropical regions (Neustupa \& ŠKaloud 2008) than to comparable published data from temperate regions (NAKANO et al. 1991; Mikhailyuk 1999; MikhailyuK et al. 2001). In addition, the results showed that corticolous phototrophic biofilms growing on trees of a single forest stand were non-randomly structured in relation to abiotic factors. Within a limited area of a 3 ha forest stand, we presume that microorganisms do not have any dispersal limitations among different tree trunks (SHARma et al. 2007). Aerial transport of aerosolised microalgal cells, colonies or filaments is thought to be the most effective means of their dispersal (SHARMA et al. 2007). Extensive dispersion of propagules should lead to incessant homogenisation of the species pool of potential new colonisers (ShARMA \& Singh 2010). Hence, the observed non-random pattern of species richness and species composition of microalgae implies that environmental filtering has a strong effect on community differentiation within the investigated forest stand.

Species richness of microalgae in biofilms was primarily correlated with the bark surface $\mathrm{pH}$, which is determined by the host tree species. The effect of $\mathrm{pH}$, indirectly coupled with the availability of nutrients (ELLIS 2012), has widely been recognised as a key factor structuring the diversity and community structure of aerial or semi-terrestrial microalgae (HofFMANN 1989, Johansen 2010, Hásek et al. 2011, Ress \& Lowe 2013), as well as corticolous lichens and mosses (e.g., BARKMAn 1958, GonZÁlez-Mancebo et al. 2003) and myxomycetes (ScArborough et al. 2009). Many OTUs were only found in samples with higher bark $\mathrm{pH}$, but we did not find any evidence of strictly acidophilic taxa. The bark of spruce trees, which typically had the lowest $\mathrm{pH}$ values, was dominated by coccoid trebouxiophycean green microalgae, such as Stichococcus sp., Pseudococcomyxa sp. and Apatococcus sp., and by non-lichenised cells identified as Trebouxia or Asterochloris. However, all of the OTUs classified into these genera were also abundant in the samples taken from various host trees and across a wide $\mathrm{pH}$ range. Therefore, we assume that the OTUs occuring in biofilms from strongly acidic bark $(\mathrm{pH}<4.0)$ were acidotolerant rather than strictly acidophilic. This pattern is strikingly 

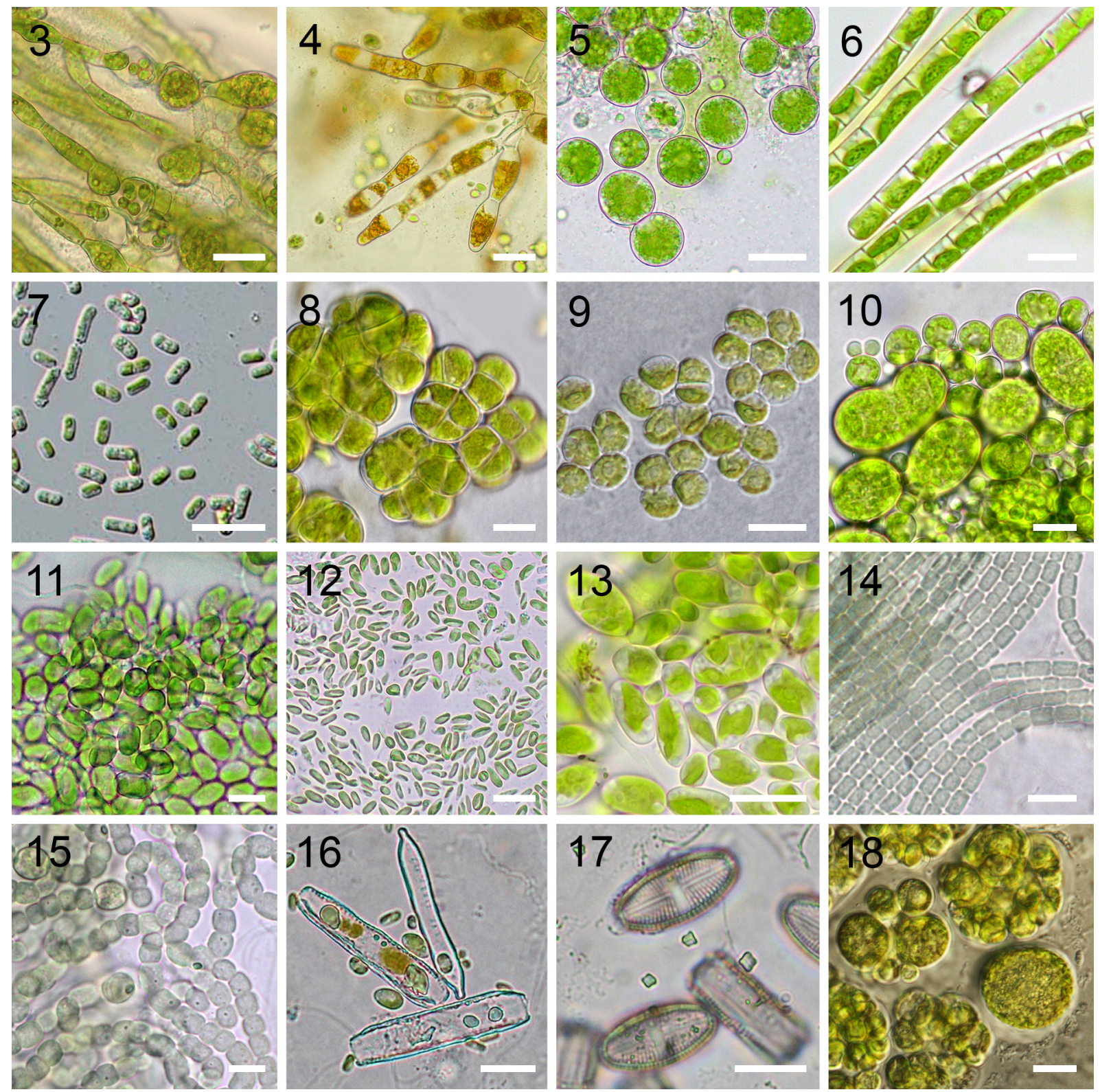

Figs 3-18. LM micrographs of selected microalgae occurring in corticolous biofilms: (3-4) Trentepohlia sp., (5) Trebouxia/Asterochloris sp., (6) Klebsormidium sp., (7) Stichococcus bacillaris, (8) Apatococcus lobatus, (9) Interfilum terricolum, (10) Dictyochloropsis irregularis, (11) Coccomyxa sp. 2, (12) Pseudococcomyxa sp., (13) Chloroidium ellipsoideum, (14) Pseudanabaena sp., (15) Nostoc sp., (16) Hantzschia amphyoxis, (17) Luticola mutica, (18) Botrydiopsis constricta. Scale bars represent $10 \mu \mathrm{m}$.

similar to the results of LuKEŠOví \& HOFFMANN (1996), who also did not detect any strict acidophilic taxa in algal microcommunities of acidified soils. Conversely, a number of the OTUs were apparently unable to grow on strongly acidic bark; therefore, we conclude that low bark $\mathrm{pH}$ most likely plays a key role as a stress factor shaping the corticolous microalgal communities.

However, even when the $\mathrm{pH}$-effect was controlled, the taxonomic identity of the host tree species still spanned a considerable proportion of the variance in the microalgal community structure. Likewise, NEUSTUPA \& ŠTIFTEROVÁ (2013) observed analogous patterns in the composition of biofilms among regions, and SPIER et al. (2010) reported a similar phenomenon in lichen corticolous communities in urban habitats. The other attributes of tree bark (besides $\mathrm{pH}$ ) that may be responsible for the observed variation remain unknown. LÜtTGe \& BÜDEL (2010) and HäUBNeR et al. (2006) found that varying tolerance to desiccation stress may be a key factor determining the survival ability of microalgal taxa in aerial biofilms. The tree species-dependent bark water-holding capacity (related to bark thickness, hardness, texture and stability) and stem flow (resulting from tree crown morphology) directly influence the intensity of desiccation stress and are important determinants of the distribution of various bark-dwelling organisms (Valové \& Bieleszová 2008; BüDEL 2011; ElLIs 2012). Consequently, we pro- 

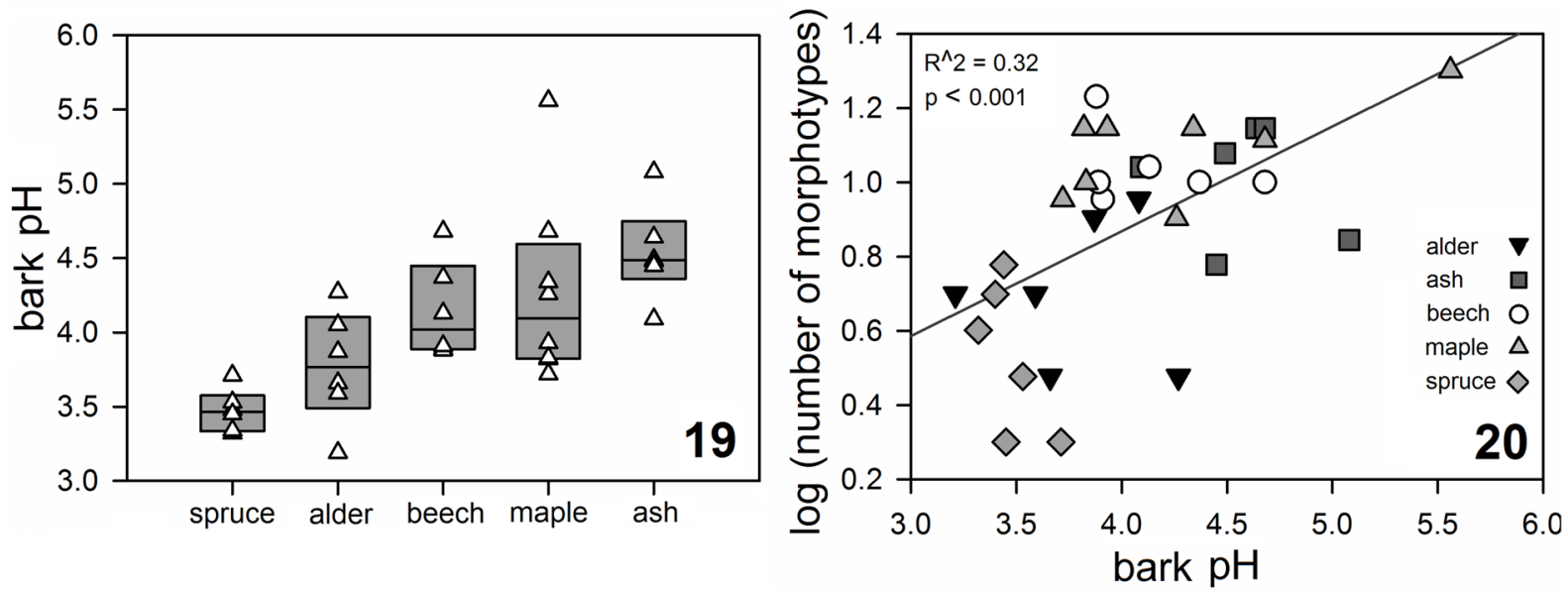

Figs 19-20. Bark pH of the samples: (19) bark surface $\mathrm{pH}$ values of samples taken from different tree species, (20) linear regression analysis of local species richness vs. bark $\mathrm{pH}$.
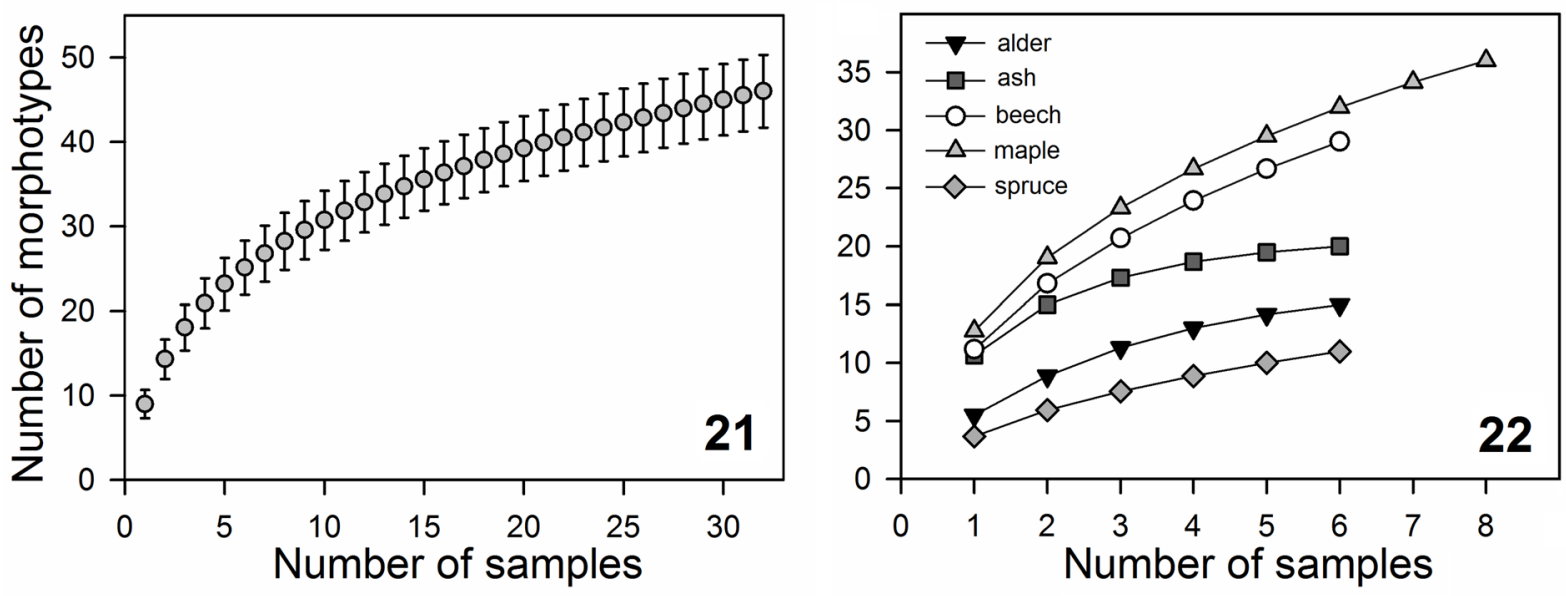

Figs 21-22. Sample-based rarefaction curves: (21) unsaturated relationship between the number of samples and the total species richness, $5-95 \%$ confidence intervals included; (22) rarefaction curves for individual host tree species.
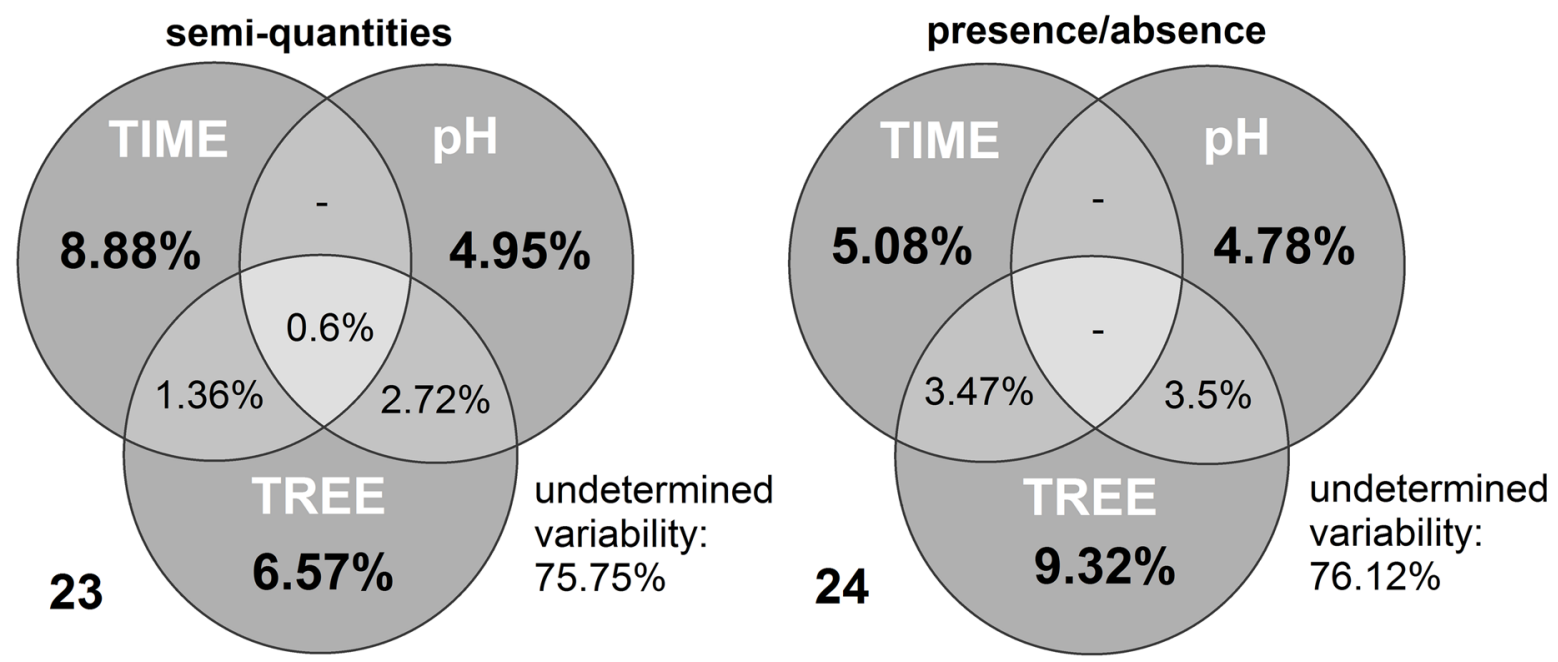

Figs 23-24. Variance partition based on RDA analyses. Proportions of variance resolved by sample $\mathrm{pH}$, host tree species, sampling date and their combinations are given. 


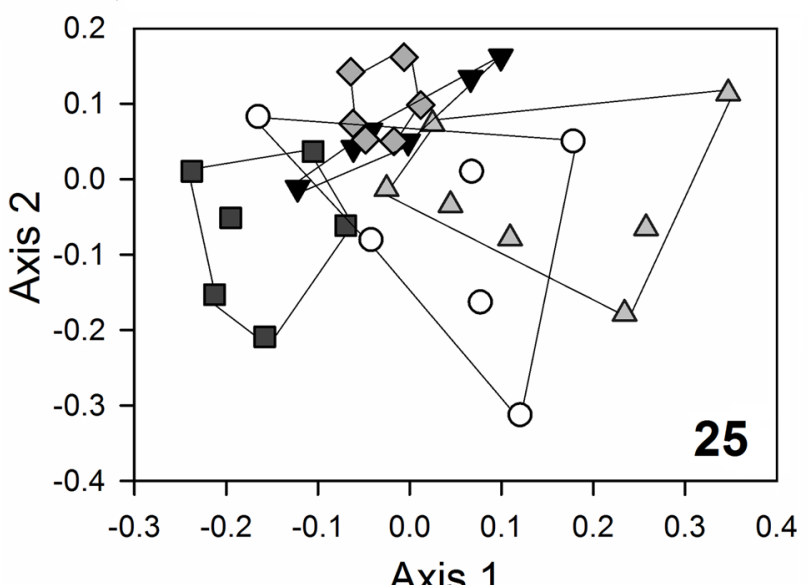

Axis 1

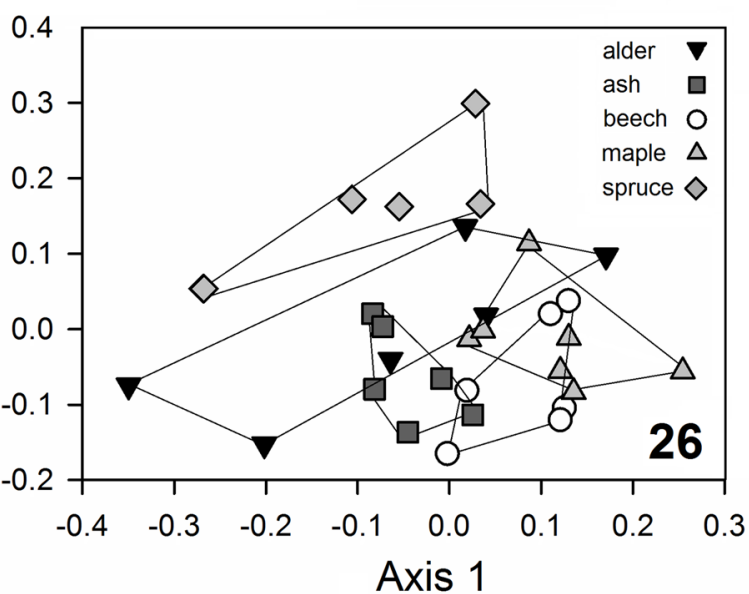

Fig. 25-26. Non-metric MDS ordination diagrams showing the differences in species composition of the samples: (25) semi-quantities, Manhattan distance index, 2D stress $=0.24,3 \mathrm{D}$ stress $=0.19 ;(26)$ presence/absence data matrix, Jaccard similarity index, 2D stress $=0.27$, $3 \mathrm{D}$ stress $=0.22$.

pose that under the temperate climatic conditions of the studied locality, typified by frequent dry periods and relatively low annual precipitation (c. $500 \mathrm{~mm}$ ), these species-specific bark characteristics, which are related to the bark's ability to absorb and retain water, may be important for the mesoscale distribution of individual algal taxa. This factor may also have led to the pattern observed by Neustupa \& ŠTifterová (2013); the influence of different host tree species (and $\mathrm{pH}$ ) on the corticolous assamblages was significantly more intensive in the temperate localities with less precipitation than in the more humid sub-Mediterranean region.

Interestingly, the temporal difference among sampling dates was also significantly related to the community structure of the biofilms. This relationship was more pronounced in the dataset based on the abundances of taxa than in the presence/absence data matrix. Therefore, time-related variation was related to the relative abundances of individual taxa, possibly boosted by short-term favourable conditions, which may have supported growth of a particular OTUs. However, this study was not specifically designed to investigate temporal effects; further work on this topic is apparently needed.

In summary, this study demontrated the nonrandom structure of corticolous phototrophic communities within a single forest stand in a temperate region. The observed pattern suggested possible effects of deterministic processes, such as individual species sorting along environmental gradients ( $\mathrm{pH}$, humidity). Additional research focusing on both the physiological strategies of individual species and the effects of particular environmental factors acting at the host tree species level, such as the differential water retention capacity of bark and its importance with regard to the varying climatic conditions of the localities, would provide valuable information about the ecological dynamics and adaptive strategies for survival of microal- gae in aerial biofilms.

ACKnowledgements

This study was supported by a grant from the Czech Science Foundation (no. P506/12/0955). The authors would like to thank Pavel Škaloud and Petra Mutinová for their kind assistance with identification of green algae and diatoms. The authors also thank BioEdit proofreading service for the English language and style corrections.

\section{REFERENCES}

ANDERSEN, R.A. (2005): Algal culturing techniques. - Elsevier Academic Press, London.

BARKMAn, J.J. (1958): Phytosociology and ecology of cryptogamic epiphytes. - Van Gorkum, Assen.

Büdel, B. (2011): Eukaryotic Algae. - In: LÜtTGE, U.; BeCK, E. \& BARTELs, D. (eds): Plant Desiccation Tolerance. - 45-63 pp., Springer, Berlin - Heidelberg.

CÁceres, M.E.; Lücking, R. \& Rambold, G. (2007): Phorophyte specificity and environmental parameters versus stochasticity as determinants for species composition of corticolous crustose lichen communities in the Atlantic rain forest of northeastern Brazil. - Mycological Progress 6: 117-136.

Caruso, A. \& Thor, G. (2007): Importance of different tree fractions for epiphytic lichen diversity on Picea abies and Populus tremula in mature managed boreonemoral Swedish forests. - Scandinavian Journal of Forest Research 22: 219-230.

Colwell, R.K.; MaO, C.X. \& Chang, J. (2004): Interpolating, extrapolating, and comparing incidence-based species accumulation curves. - Ecology 85: 2717-2727.

Cutler, N.A.; Oliver, A.E.; Viles, H.A.; Ahmad, S. \& WhiTELEY, A.S. (2013): The characterisation of eukaryotic microbial communities on sandstone buildings in Belfast, UK, using TRFLP and 454 pyrosequencing. - International Biodeterioration and Biodegradation 82: $124-133$

Davies, L.O.; Schäfer, H.; Marshall, S.; Bramke, I.; Oli- 
VER, R.G. \& BENDING, G.D. (2013): Light structures phototroph, bacterial and fungal communities at the soil surface. - PLoS One 8: e69048.

ElLIS, C.J. (2012): Lichen epiphyte diversity: a species, community and trait-based review. - Perspectives in Plant Ecology 14: 131-152.

EtTL, H. \& GÄrTnER, G. (1995): Syllabus der Boden-, Luftund Flechtenalgen. - Gustav Fisher Verlag, Stuttgart.

Freystein, K.; Salisch, M. \& Reisser, W. (2008): Algal biofilms on tree bark to monitor airborne pollutants. Biologia 63: 866-872.

Freystein, K. \& Reisser, W. (2010): Green biofilms on tree barks: More than Just Algae. - In: SECKBACH, J. \& Grube, M. (eds): Symbioses and Stress. - 557-573 pp., Springer, Netherlands.

FriedL, T. \& Rybalka, N. (2012): Systematics of the green algae: A brief introduction to the current status. - In: Lüttge, U.; Beyschlag, W.; Büdel, B. \& Francis, D. (eds): Progress in Botany 73. - 259-280 pp., Springer, Berlin.

GÄRTNER, G. (1994): Zur Taxonomie aerophiler grüner Algenanflüge an Baumrinden. - Berichte des naturwissenschaftlich-medizinischen Vereins in Innsbruck 81: 51-59.

Gonzalez-Mancebo, J.M.; Losada-Lima, A. \& McAlister, S. (2003): Host specificity of epiphytic bryophyte communities of a laurel forest on Tenerife (Canary Islands, Spain). - The Bryologist 106: 383-394.

HáJek, M.; RoleČek, J.; Cottenie, K.; Kintrová, K.; Horsák, M.; PoulíčKová, A.; HáJKová, P.; FránKovÁ, M. \& DítĚ, D. (2011): Environmental and spatial controls of biotic assemblages in a discrete semi-terrestrial habitat: comparison of organisms with different dispersal abilities sampled in the same plots. - Journal of Biogeography 38: 1683-1693.

HAMmer, Ø.; Harper, D.A.T. \& RYAN, P.D. (2001): PAST: Paleontological statistics software package for education and data analysis. Palaeontologia Electronica 4(1): 9pp. Available from: http://palaeo-electronica. org/2001_1/past/issue1_01.htm.

Hänninen, O.; RuUSKanen, J. \& OKSANen, J. (1993): A method for facilitating the use of algae growing on tree trunks as bioindicators of air quality. - Environmental Monitoring Assessment 28: 215-220.

Häubner, N.; Schumann, R. \& Karsten, U. (2006): Aeroterrestrial microalgae growing in biofilms on facades response to temperature and water stress. - Microbial Ecology 51: 285-293.

Hedenås, H.; Blomberg, P. \& Ericson, L. (2007): Significance of old aspen (Populus tremula) trees for the occurrence of lichen photobionts. - Biological Conservation 135 : 380-387.

Hoffmann, L. (1989): Algae of terrestrial habitats. - Botanical Review 55: 77-105.

JoHANSEN, J.R. (2010): Diatoms of aerial habitats. - In: SMOL, J.P. \& Stoermer, E.F. (eds): The diatoms: Applications for the Environmental and Earth Sciences. - 465-472 pp., Cambridge University Press, Cambridge.

Karsten, U. \& Holzinger, A. (2014): Green algae in alpine biological soil crust communities: acclimation strategies against ultraviolet radiation and dehydration. - Biodiversity and Conservation 23: 1845-1858.

Kitzing, C.; Pröschold, T. \& Karsten, U. (2014): UV-Induced effects on growth, photosynthetic performan- ce and sunscreen contents in different populations of the green alga Klebsormidium fluitans (Streptophyta) from alpine soil crusts. - Microbial Ecology 67: 327-340.

KomÁReK, J. \& ANAGNostidis, K. (2005): Süßwasserflora von Mitteleuropa, Cyanoprokaryota 19/2. Teil: Oscillatoriales. -759 pp., Elsevier, München.

KulichovÁ, J.; ŠKaloud, P. \& Neustupa, J. (2014): Molecular diversity of green corticolous microalgae from two sub-Mediterranean European localities. - European Journal of Phycology 49: 345-355.

Larsen, R.S.; Bell, J.N.B.; James, P.W.; Chimonides, P.J.; Rumsey, F.J.; Tremper, A. \& Purvis, O.W. (2007): Lichen and bryophyte distribution on oak in London in relation to air pollution and bark acidity. - Environmental Pollution 146: 332-340.

Lemes-Da-Silva, N.M.; Zanini Branco, L.H. \& Necchi JÚNIOR, O. (2012): Corticolous cyanobacteria from tropical forest remnants in northwestern São Paulo State, Brazil. - Brazilian Journal of Botany 35: 169-179.

Lewis, J.E. \& ElLIS, C.J. (2010): Taxon-compared with traitbased analysis of epiphytes, and the role of tree species and tree age in community composition. - Plant Ecology and Diversity 3: 203-210.

Lopez-Bautista, J.M.; Rindi, F. \& Casamatta, D. (2007): The systematics of subaerial algae. - In: SECKBACH, J. (ed): Algae and cyanobacteria in extreme environments. - 599-617 pp., Springer, Netherlands.

LuKEŠovÁ, A. \& HoffmAnN, L. (1996): Soil algae from acid rain impacted forest areas of the Krušné hory Mts. Vegetatio 125: 123-36.

LÜTTGE, U. \& BÜDEL, B. (2010): Resurrection kinetics of photosynthesis in desiccation-tolerant terrestrial green algae (Chlorophyta) on tree bark. - Plant Biology 12: 437-444.

Ma, S.; Huss, V.A.; Tan, D.; Sun, X.; Chen, J.; Xie, Y. \& Zhang, J. (2013): A novel species in the genus $\mathrm{He}$ veochlorella (Trebouxiophyceae, Chlorophyta) witnesses the evolution from an epiphytic into an endophytic lifestyle in tree-dwelling green algae. European Journal of Phycology 48: 200-209.

Marmor, L. \& Randlane, T. (2007): Effects of road traffic on bark $\mathrm{pH}$ and epiphytic lichens in Tallinn. - Folia Cryptogamica Estonica 43: 23-37.

Marmor, L.; TõrRa, T. \& Randlane, T. (2010): The vertical gradient of bark $\mathrm{pH}$ and epiphytic macrolichen biota in relation to alkaline air pollution. - Ecological Indicators 10: 1137-1143.

Marmor, L. \& Degtjarenko, P. (2014): Trentepohlia umbri$n a$ on Scots pine as a bioindicator of alkaline dust pollution. - Ecological Indicators 45: 717-720.

McCune, B.; Rosentreter, R.; Ponzetti, J.M. \& Shaw, D.C. (2000): Epiphyte habitats in an old conifer forest in western Washington, USA. - The Bryologist 103: $417-427$.

MikhaiLyuK, T.I. (1999): Eusubaerial algae of Kaniv Nature Reserve (Ukraine). - Ukrayins'kyi botanichnyi zhurnal 56: 507-513.

Mikhailyuk, T.I.; Tsarenko, P.M.; Nevo, E. \& Wasser, S.P. (2001): Additions to the study of aerophytic eukaryotic algae of Israel. - International Journal on Algae 3: 19-39.

Mikhailyuk, T.I.; Sluiman, H.J.; Massalski, A.; Mudimu, O.; Demchenko, E.M.; Kondratyuk, S.Y. \& Friedl, T. (2008): New streptophyte algae from terrestrial 
habitats and an assessment of the genus Interfilum (Klebsormidiophyceae, Streptophyta). - Journal of Phycology 44: 1586-1603.

Nakano, T.; Handa, S. \& Takeshita, S. (1991): Some corticolous algae from the Taishaku-kyô Gorge, western Japan. - Nova Hedwigia 52: 427-451.

NĚmcovÁ, Y.; EliÁš, M.; ŠKaloud, P.; Hodač, L. \& NeustuPa, J. (2011): Jenufa gen. nov.: A new genus of coccoid green algae (Chlorophyceae, inceartae sedis) previously recorded by environmental sequencing. - Journal of Phycology 47: 928-938.

NeustuPA, J. \& ŠKaloud, P. (2008): Diversity of subaerial algae and cyanobacteria on tree bark in tropical mountain habitats. - Biologia 63: 806-812.

Neustupa, J.; Němcová, Y.; Veselá, J.; Steinová, J. \& ŠKaLoud, P. (2013): Parachloroidium gen. nov. (Trebouxiophyceae, Chlorophyta), a novel genus of coccoid green algae from subaerial corticolous biofilms. Phycologia 52: 411-421.

Neustupa, J. \& Štifterová, A. (2013): Distribution patterns of subaerial corticolous microalgae in two European regions. - Plant Ecology and Evolution 146: 279289

Oksanen, J.; Blanchet, F.G.; Kindt, R.; Legendre, P.; MinChin, P.R.; O’Hara, R.B.; Simpson, G.L.; Solymos, P.; Stevens, M.H.H. \& Wagner, H. (2011): Vegan: Community Ecology Package. R package version 2.0-0 [online]. Available from http://CRAN.R-project.org/ package $=$ vegan

Poikolainen, J.; Lippo, H.; Hongisto, M.; Kubin, E.; MikKoLA, K. \& LindGren, M. (1998): On the abundance of epiphytic green algae in relation to the nitrogen concentrations of biomonitors and nitrogen deposition in Finland. - Environmental Pollution 102: 85-92.

R Development Core Team (2013): R: A language and environment for statistical computing, ver. 2.15.3. - R Foundation for Statistical Computing, Vienna.

Rambo, T.R. (2010): Structure and composition of corticolous epiphyte communities in a Sierra Nevada oldgrowth mixed-conifer forest. - The Bryologist 113: $55-71$.

Ress, J.A. \& Lowe, R.L. (2013): Contrast and comparison of aerial algal communities from two distinct regions in the U.S.A., the Great Smoky Mountains National Park (TN) and the Lake Superior region. - Fottea 13: $165-172$

Rindi, F.; Allali, H.A.; Lam, D.W. \& Lopéz-Bautista, J.M. (2009): An overview of the biodiversity and biogeography of terrestrial green algae. - In: REscigno, V. \& Maletta, S. (eds): Biodiversity Hotspots. - 105-122 pp., Nova Science Publishers, New York.

Rindi, F.; Mikhailyuk, T.I.; Sluiman, H.J.; Friedl, T. \& López-Bautista, J.M. (2011): Phylogenetic relationships in Interfilum and Klebsormidium (Klebsormidiophyceae, Streptophyta). - Molecular Phylogenetics and Evolution 58: 218-231.

Scarborough, A.R.; Keller, H. W. \& Ely, J.S. (2009): Species assemblages of tree canopy myxomycetes related to bark pH. - Castanea 74: 93-104.

Schmidt, J.; Kricke, R. \& Feige, G. B. (2001): Measurements of bark $\mathrm{pH}$ with a modified flathead electrode. - The Lichenologist 33: 456-460.

Sharma, N.K.; RaI, A.K.; Singh, S. \& Brown, R.M. (2007): Airborne algae: their present status and relevance. Journal of Phycology 43: 615-627.
Sharma, N.K. \& Singh, S. (2010): Differential aerosolization of algal and cyanobacterial particles in the atmosphere. - Indian Journal of Microbiology 50: 468-473.

Spier, L.; Van Dobben, H. \& Van Dort, K. (2010): Is bark $\mathrm{pH}$ more important than tree species in determining the composition of nitrophytic or acidophytic lichen floras? - Environmental Pollution 158: 3607-3611.

STUDLAR, S.M. (1982): Host specificity of epiphytic bryophytes near Mountain Lake, Virginia. - The Bryologist 85: 27-50.

Valová, M. \& Bieleszová, S. (2008): Interspecific variations of bark's water storage capacity of chosen types of trees and the dependance on occurance of epiphytic mosses. - GeoScience Engineering 54: 45-51.

Supplementary material

the following supplementary material is available for this article:

Table S1. List of OTUs found at localities.

This material is available as part of the online article (http://fottea.czechphycology.cz/contents)

(C) Czech Phycological Society (2015)

Received February 10, 2015

Accepted March 30, 2015 